\title{
Quantitative resistance to Botrytis cinerea from Solanum neorickii
}

\author{
Richard Finkers · Yuling Bai · Petra van den Berg • Ralph van Berloo • \\ Fien Meijer-Dekens · Arjen ten Have · Jan van Kan · Pim Lindhout • \\ Adriaan W. van Heusden
}

Received: 6 November 2006/ Accepted: 8 May 2007/Published online: 7 June 2007

(C) Springer Science+Business Media B.V. 2007

\begin{abstract}
Tomato (Solanum lycopersicum) is susceptible to gray mold (Botrytis cinerea). Quantitative resistance to $B$. cinerea was previously identified in a wild relative, $S$. neorickii $\mathrm{G} 1.1601$. The $122 \mathrm{~F}_{3}$ families derived from a cross between the susceptible $S$. lycopersicum cv. Moneymaker and the partially resistant $S$. neorickii G1.1601 were tested for susceptibility to $B$. cinerea using a stem bioassay. Three putative quantitative trait loci (pQTL) were detected: pQTL3 and pQTL9 reducing lesion growth (LG) and pQTL4 reducing disease incidence (DI). For each pQTL, a putative homologous locus was identified recently in another wild tomato relative, S. habrochaites LYC4.
\end{abstract}

R. Finkers $(\bowtie) \cdot$ Y. Bai · P. van den Berg .

R. van Berloo · F. Meijer-Dekens · P. Lindhout .

A. W. van Heusden

Graduate school Experimental Plant Sciences, Laboratory

of Plant Breeding, Wageningen University, PO box 386,

Wageningen 6700 AJ, The Netherlands

e-mail: Richard.Finkers@wur.nl

A. ten Have · J. van Kan

Laboratory of Phytopathology, Wageningen University,

PO Box 8025, Wageningen 6700 EE, The Netherlands

A. ten Have

Instituto de Investigaciones Biologicas, Facultad de Ciencias Exactas y Naturales, Universidad Nacional de Mar del Plata, cc 1245 (7600) Mar del Plata, Argentina

P. Lindhout

De Ruiter Seeds, PO box 1050, Bergschenhoek 2660 BB, The Netherlands
pQTL3 was confirmed by assessing disease resistance in $\mathrm{BC}_{3} \mathrm{~S}_{1}$ and $\mathrm{BC}_{3} \mathrm{~S}_{2}$ progenies of $S$. neorickii $\mathrm{G} 1.1601$. pQTL4 was not statistically confirmed but the presence of the $S$. neorickii resistance allele reduced DI in all three tested populations. The reduction in LG of pQTL9 was not confirmed but rather, this locus conferred a reduced DI, similar to observations in the QTL study using $S$. habrochaites. The results are discussed in relation to other disease resistance loci identified in studies with other wild tomato relatives.

Keywords Botrytis cinerea · Gray mold . Quantitative trait locus (QTL) - S. neorickii · Marker assisted selection (MAS)

\section{Introduction}

Botrytis cinerea [teleomorph: Botryotinia fuckeliana (de Bary) Whetzel] is a necrotrophic fungus with a wide host range (Jarvis 1977; Elad et al. 2004). Modern hybrid tomato (Solanum lycopersicum) cultivars are susceptible to $B$. cinerea although some cultivars show a certain level of quantitative resistance (ten Have et al. 2007). The presumed polygenic inheritance has limited the success of breeding for resistance to $B$. cinerea.

Quantitative resistance to $B$. cinerea has been identified in several wild relatives of $S$. lycopersicum (Urbasch 1986; Egashira et al. 2000; Nicot et al. 
2002; ten Have et al. 2007). A stem bioassay suitable to quantify susceptibility of tomato to $B$. cinerea was used to screen a collection of wild tomato accessions (ten Have et al. 2007), and two parameters were calculated: the proportion of outgrowing lesions or disease incidence (DI) and lesion growth (LG) rate expressed as the increase in lesion size in $\mathrm{mm} /$ day. All four tested accessions of $S$. habrochaites showed quantitative resistance (ten Have et al. 2007). $S$. habrochaites LYC4 was used previously to study the genetic basis of this resistance (Finkers et al. 2007a, b) and a total of ten quantitative trait loci (QTL) were identified illustrating the genetic complexity of resistance to $B$. cinerea. Also $S$. neorickii G1.1601 showed a certain level of resistance (ten Have et al. 2007). A $F_{2}$ mapping population of $S$. lycopersicum cv. Moneymaker $\times S$. neorickii G1.1601, previously developed to identify QTLs for resistance to Oidium neolycopersici (Bai et al. 2003), was screened for susceptibility to $B$. cinerea. Since $F_{2}$ seeds were no longer available, $F_{3}$ families were used for the analysis. Segregating $\mathrm{BC}_{3} \mathrm{~S}_{1}$ families and $\mathrm{BC}_{3} \mathrm{~S}_{2}$ plants were generated in order to confirm the effects identified in the $F_{3}$ analysis. We report the identification of (putative) QTLs, from S. neorickii G1.1601 involved in resistance to $B$. cinerea. Results of this study were compared to previously identified QTLs for resistance to $B$. cinerea in $S$. habrochaites LYC4 (Finkers et al. 2007a, b).

\section{Materials and methods}

Plant material

Three tomato accessions were used in this study: $S$. lycopersicum cv. Moneymaker (hereafter referred to as $S L$ ), S. neorickii G1.1601 (hereafter referred to as $S N$ ) and $S$. habrochaites LYC4 (hereafter referred to as $S H$ ). A cross between $S L$ and $S N$ was made and an $\mathrm{F}_{2}$ population $(n=209)$ developed as described in detail by Bai et al. (2003). From this $F_{2}$ population, $\mathrm{F}_{3}$ seeds of each genotype were collected, but only $122 \mathrm{~F}_{2}$ plants produced enough $\mathrm{F}_{3}$ seeds for further study. Marker data for 75 of the $122 \mathrm{~F}_{2}$ plants used in this study were available.

For confirmation of the QTLs, three selected $\mathrm{F}_{3}$ plants were backcrossed to $S L$ to obtain $\mathrm{BC}_{1}$ seeds. Two subsequent backcrosses to $S L$ resulted in a $\mathrm{BC}_{3}$ progeny of 53 plants and marker assisted selection (MAS) was used to select three plants containing either QTL. Three $\mathrm{BC}_{3} \mathrm{~S}_{1}$ families $(n=86$ each) were genotyped to select plants homozygous $S L$ or $S N$ for the putative QTLs. A selected set of $\mathrm{BC}_{3} \mathrm{~S}_{1}$ genotypes homozygous $S N$ for the region of interest was grown to produce $\mathrm{BC}_{3} \mathrm{~S}_{2}$ seeds.

Experimental setup and stem assay

For each of the $122 \mathrm{~F}_{3}$ families, five seedlings were grown and their susceptibility to $B$. cinerea was evaluated. For logistic reasons the disease assays were divided (at random) into 13 experiments with equal numbers of plants (50 plants/week). Eight $S L$ controls were included in each experiment.

For the $\mathrm{BC}_{3} \mathrm{~S}_{1}$ families, six replicates were grown by taking cuttings of each genotype including a set of $S L, S N$, and $S H$ controls. To assess susceptibility to $B$. cinerea in the $\mathrm{BC}_{3} \mathrm{~S}_{2}$ plants, two experiments were performed. In each experiment, three replicates, grown from seeds, of each genotype was tested.

The stem assay was performed according to ten Have et al. (2007). In short, stems of 6-8-week-old plants were cut into six pieces of five $\mathrm{cm}$ length and the top of each segment was inoculated with a droplet of $5 \mu \mathrm{l}$ inoculum, containing $\sim 10^{6}$ conidia per $\mathrm{ml}$. Inoculum of B. cinerea strain B05.10 was prepared according to Benito et al. (1998). Incubations were performed at $15^{\circ} \mathrm{C}$ in the dark at $100 \%$ relative humidity. The infection progress was measured at day four and five after inoculation using a Vernier caliper. For each genotype, the percentage of successfully infected stem pieces was calculated (DI). The LG rate was calculated as the increase in lesion size between day four and five ( $\mathrm{mm} /$ day) for the infected stem pieces.

DNA isolation and marker analysis

Twelve plants of each $\mathrm{F}_{3}$ family were grown and one leaf was harvested from each plant and pooled for DNA isolation in order to deduce the original $F_{2}$ genotype. The AFLP ${ }^{\mathrm{TM}}$ and CAPS analysis of the $\mathrm{F}_{3}$, $\mathrm{BC}_{3}$, and $\mathrm{BC}_{3} \mathrm{~S}_{1}$ populations were performed as described previously (Finkers et al. 2007a, b). The following ten AFLP primer combinations were used for genotyping: P14M48, P14M49, P14M50, 
P14M60, P14M61, P15M48, P18M50, P18M51, $\mathrm{P} 22 \mathrm{M} 50$, and P22M51. AFLP primer nomenclature and adapter sequences have been described previously by Bai et al. (2003).

CAPS and SCAR primers were obtained from the "Solanaceae Genomics Website" (http://www.sgn. cornell.edu) or designed on sequences of genomic or cDNA clones available from the same source. Polymorphisms between $S L$ and $S N$ were determined using the CAPS digestion approach described by Bai et al. (2004). Markers, PCR conditions and restriction endonucleases used for genotyping are presented in Table 1.
Data analysis

Marker data were analyzed and a genetic linkage map was calculated with Joinmap ${ }^{\circledR} 3.0$ (van Ooijen and Voorrips 2001). The susceptibility of the $F_{2}$ genotype was estimated by taking the means of the replicated disease assays of five $\mathrm{F}_{3}$ plants. Phenotypic data of the $\mathrm{BC}_{3} \mathrm{~S}_{1}$ and $\mathrm{BC}_{3} \mathrm{~S}_{2}$ plants were analyzed using the general linear model (GLM) approach as implemented in SPSS 12.0 (SPSS Inc., Chicago, IL, USA). The minimal adequate models for DI and LG were determined independently in the data of the $\mathrm{BC}_{3} \mathrm{~S}_{1}$ families and $\mathrm{BC}_{3} \mathrm{~S}_{2}$ plants. This resulted in the

Table 1 Primer sequences, lengths of PCR products and enzymes revealing a polymorphism for CAPS/SCAR markers

\begin{tabular}{|c|c|c|c|c|c|c|c|}
\hline $\begin{array}{l}\text { Marker } \\
\text { name }\end{array}$ & Chromosome & Primer sequence $\left(5^{\prime}-3^{\prime}\right)$ & $\begin{array}{l}\text { Observed PRC } \\
\text { product length } \\
\text { (bp) }\end{array}$ & $\begin{array}{l}\text { Annealing } \\
\text { temperature } \\
\left({ }^{\circ} \mathrm{C}\right)\end{array}$ & $\begin{array}{l}\text { Marker } \\
\text { type }\end{array}$ & Enzyme & Source $^{\mathrm{a}}$ \\
\hline TG40 & 3 & $\begin{array}{l}\text { GCGAGCTCGAATTCAATTCCAAC } \\
\text { CGGGATTTTAGTTTTTCCGATCC }\end{array}$ & 450 & 55 & CAPS & Alu $\mathrm{I}$ & PBR \\
\hline TG599 & 3 & $\begin{array}{l}\text { GCATGCCTGCAGAGTGGTC } \\
\text { ATTCGCTACCTTGAGGGCTG }\end{array}$ & 350 & 65 & CAPS & BspLI & PBR \\
\hline TG549 & 3 & $\begin{array}{l}\text { ATGGAGAGAAGCTGGAACAC } \\
\text { TTCTTAGAGCCCACCAGCAC }\end{array}$ & 400 & 55 & CAPS & MseI & PBR \\
\hline $\mathrm{T} 1143$ & 3 & $\begin{array}{l}\text { GGAGAATGGGCATCTACAAA } \\
\text { CCTTTAGGATGGATTCCG }\end{array}$ & $\begin{array}{l}S N: \\
\quad 1580+1050 / \\
S L: 1000\end{array}$ & 55 & SCAR & & PBR \\
\hline T0707 & 4 & $\begin{array}{l}\text { TCGTGGATTATGGGCTTCTT } \\
\text { GGTAAGGCTGCAACACATCA }\end{array}$ & 560 & 55 & CAPS & $D d e \mathrm{I}$ & PBR \\
\hline TG339 & 4 & $\begin{array}{l}\text { GAAACCTTACCCCTCTA } \\
\text { CGCTGTTTCTTGCCATTT }\end{array}$ & 500 & 46 & CAPS & $\operatorname{Hinf} \mathrm{I}$ & PBR \\
\hline TG272 & 4 & $\begin{array}{l}\text { GATTTTGCCCCCTCTACCA } \\
\text { ACATCTTTTCCTTCCCTCTGC }\end{array}$ & 352 & 55 & CAPS & $\operatorname{Hinf} \mathrm{I}$ & PBR \\
\hline TG264 & 4 & $\begin{array}{l}\text { GGAACAGGTCAGGACAGCAT } \\
\text { TGGCTAACTGACGAAGACGA }\end{array}$ & 520 & 55 & CAPS & $M n l \mathrm{I}$ & PBR \\
\hline $\mathrm{T} 1405$ & 4 & $\begin{array}{l}\text { CACCAACAACTAGCCCTTGA } \\
\text { AAGCAATTCCTCCAGCTTCA }\end{array}$ & 535 & 55 & CAPS & BsaJI & SGN \\
\hline TG555 & 4 & $\begin{array}{l}\text { AATTCGGAGCTCACTGCTTC } \\
\text { AGTACGGCATGCTTGCTATC }\end{array}$ & 430 & 55 & CAPS & НруСH4IV & PBR \\
\hline TG10 & 9 & $\begin{array}{l}\text { ATGATATCCACACCCCTGGA } \\
\text { ATGCCTCGAAATTCAAATGC }\end{array}$ & 587 & 55 & CAPS & HaeIII & PBR \\
\hline $\operatorname{Tm} 2 \mathrm{a}$ & 9 & $\begin{array}{l}\text { AGCGTCACTCCATACTTGGAATAA } \\
\text { AGCGTCACTCAAAATGTACCCAAA }\end{array}$ & 1600 & 53 & CAPS & AccI & $\begin{array}{l}\text { Sobir } \\
\text { et al. } \\
\text { (2000) }\end{array}$ \\
\hline TG551 & 9 & $\begin{array}{l}\text { CAACGAAAACCTTGGCACTC } \\
\text { GAGATGAGCAGCATATGGAG }\end{array}$ & 350 & 55 & CAPS & НруСH4IV & PBR \\
\hline
\end{tabular}

a PBR: developed at Wageningen University laboratory of Plant Breeding, mainly using data from SGN. SGN: primers published in the SGN database (http://www.sgn.cornell.edu) or published previously and references are given 
following models: $\mathrm{DI}=$ constant + genotype + block and $\mathrm{LG}=$ constant + genotype + block + genotype $\times$ block.

Quantitative trait locus analysis of the $F_{3}$ and $\mathrm{BC}_{3} \mathrm{~S}_{1}$ populations were performed using the Kruskal-Wallis analysis as embedded in MapQTL ${ }^{\circledR}$ 5.0 (van Ooijen 2003). Data of the grouped $\mathrm{BC}_{3} \mathrm{~S}_{2}$ plants were analyzed by comparing mean observations of each group to the mean observation of $S L$ using a Dunnett test (Dunnett 1955). A probability of $P<0.05$ was used to refer to a QTL as significant. Linkage maps were drawn using MapChart (Voorrips 2002). The correlation between traits was examined by interpreting Pearson correlation coefficients.

\section{Results}

Analysis of the $\mathrm{F}_{3}$ lines

$\mathrm{F}_{3}$ seeds of the cross between the susceptible cultivar $S$. lycopersicum cv. Moneymaker (SL) and S. neorickii G1.1601 (SN) were available (Bai et al. 2003) in sufficient quantity for 122 of the original $209 \mathrm{~F}_{2}$ plants. For 75 of these $122 \mathrm{~F}_{2}$ individuals, marker data were available; therefore we decided to (re) genotype all $122 \mathrm{~F}_{3}$ families. Ten AFLP primer combinations resulted in a total of 234 markers: 120 $S L$ specific and $114 S N$ specific. 192 AFLP markers were placed on the paternal and maternal linkage maps (data not shown).

A quantitative $B$. cinerea disease assay on stem segments (ten Have et al. 2007) yielded data on DI and LG. The frequency distributions of both traits suggested normal, quantitative trait characteristics (data not shown). The susceptible control, $S L$, showed a DI and LG comparable to previous experiments (Table 2; Finkers et al. 2007a). Kruskal-Wallis (KW) analysis identified three linkage groups putatively containing a QTL (pQTL) for decreased susceptibility to B. cinerea. Based on the map of Bai et al. (2003) these linkage groups could be assigned to Chromosomes 3, 4, and 9 and the pQTLs will be referred to as pQTL3, pQTL4, and pQTL9 accordingly. To integrate the maternal and paternal linkage groups of Chromosome 3, 4, and 9, thirteen codominant CAPS markers were developed (Table 1). Using the integrated linkage maps, the effect of each pQTL was recalculated using KW analysis (Table 3). All three pQTL regions showed a skewed segregation resulting in a deficit of plants homozygous $S L$ for pQTL3 and pQTL4 and a deficit of plants homozygous $S N$ for pQTL9 (Table 3). In spite of the correlation between DI and LG (Pearson: $r=0.258$ and $P<0.01$ ), all pQTLs were associated with a single trait: pQTL3 and pQTL9 conferred a reduced LG while pQTL4 conferred a reduced DI.

Confirmation of the QTLs using $\mathrm{BC}_{3} \mathrm{~S}_{1}$ and $\mathrm{BC}_{3} \mathrm{~S}_{2}$ plants

Fifty-three $\mathrm{BC}_{3}$ plants were genotyped using AFLP and three $\mathrm{BC}_{3}$ plants were selected heterozygous for the alleles of either pQTL3, pQTL4 or pQTL9 in a genetic background as similar as possible to the recurrent parent $S L$ (Table 4). Only one $\mathrm{BC}_{3}$ plant was identified containing the $S N$ allele of pQTL9. However, this plant was also heterozygous for the pQTL3 and pQTL4 alleles. Three $\mathrm{BC}_{3} \mathrm{~S}_{1}$ families were grown and MAS was used to obtain a more balanced test design (Table 4). In 3 of the 20 plants homozygous for the $S N$ allele of pQTL9, $S N$ alleles of pQTL3 and pQTL4 were absent. As a result, experiments aimed at confirming pQTL9 were only performed using $\mathrm{BC}_{3} \mathrm{~S}_{2}$ lines.

While assessing susceptibility to $B$. cinerea in the $\mathrm{BC}_{3} \mathrm{~S}_{1}$ families, only the first experiment showed a sufficient level of infection (mean DI of 63\%;

Table 2 Mean disease incidence (DI) and lesion growth (LG) of the controls

\begin{tabular}{|c|c|c|c|c|c|c|c|c|c|}
\hline \multirow[t]{2}{*}{ Population } & \multicolumn{3}{|l|}{$S L$} & \multicolumn{3}{|l|}{$S N$} & \multicolumn{3}{|c|}{$S H$} \\
\hline & $n^{\mathrm{a}}$ & DI & LG & $n$ & DI & LG & $n$ & DI & LG \\
\hline $\mathrm{F}_{3}$ & 104 & $70 \pm 7$ & $6.9 \pm 0.3$ & & & & & & \\
\hline $\mathrm{BC}_{3} \mathrm{~S}_{1}$ & 14 & $70 \pm 7$ & $6.6 \pm 0.3$ & 7 & $71 \pm 9$ & $5.1 \pm 0.3$ & 7 & $45 \pm 9$ & $4.8 \pm 0.4$ \\
\hline $\mathrm{BC}_{3} \mathrm{~S}_{2}$ & 57 & $55 \pm 3$ & $5.3 \pm 0.2$ & 11 & $36 \pm 7$ & $5.1 \pm 0.4$ & 4 & $16 \pm 12$ & $1.8 \pm 0.9$ \\
\hline
\end{tabular}

${ }^{\text {a }}$ Number of plants tested 
Table 3 Effect of the pQTLs identified in the $\mathrm{F}_{3}$ population

\begin{tabular}{|c|c|c|c|c|c|c|c|c|c|}
\hline \multirow[t]{2}{*}{ Marker } & \multirow[t]{2}{*}{ QTL } & \multicolumn{4}{|l|}{ DI (\%) } & \multicolumn{4}{|c|}{ LG (mm/day) } \\
\hline & & $S L^{a}$ & $h$ & $S N$ & $P^{b}$ & $S L$ & $h$ & $S N$ & $P$ \\
\hline TG599 & pQTL3-LG & $51(11)$ & $50(49)$ & $45(33)$ & 0.410 & $5.6(11)$ & $5.4(49)$ & $5.0(33)$ & 0.063 \\
\hline TG339 & pQTL4-DI & 59 (13) & $47(31)$ & 47 (47) & 0.092 & 5.7 (13) & $5.0(31)$ & $5.3(47)$ & 0.188 \\
\hline TG551 & pQTL9-LG & $47(31)$ & $50(53)$ & 49 (19) & 0.643 & $5.6(31)$ & $5.2(53)$ & $5.0(19)$ & 0.022 \\
\hline
\end{tabular}

Mean values for disease incidence (DI) and lesion growth (LG) are presented, along with their significances as determined using a Kruskal-Wallis test

a $S L$ denotes homozygous for the alleles of S. lycopersicum, $S N$ homozygous for the alleles of $S$. neorickii, and $h$ describes the heterozygous class. The number of observations within each class is indicated between parentheses

b Significance

Table 4 Description of the three $\mathrm{BC}_{3} \mathrm{~S}_{1}$ families

\begin{tabular}{lllll}
\hline QTL & Trait & Additional in $\mathrm{BC}_{3}$ plants & Segregation of the $\mathrm{BC}_{3} \mathrm{~S}_{1}$ families & ${\text { Number of } \mathrm{BC}_{3} \mathrm{~S}_{1} \text { plants evaluated }}^{\mathrm{a}, \mathrm{b}}$ \\
\hline pQTL3 & LG & Parts C2 and C6 & $21: 33: 16$ & $17: 17: 16$ \\
pQTL4 & DI & Parts C1 and C12 & $21: 40: 25$ & $17: 17: 15$ \\
pQTL9 & LG & pQTL3, pQTL4 and part C12 & $25: 41: 20$ & $20: 10: 20$ \\
\hline
\end{tabular}

Each pQTL and the additional introgressions for each family are described. Initially, $86 \mathrm{BC}_{3} \mathrm{~S}_{1}$ plants were grown for each family. After marker assisted selection (MAS), 50 plants were selected to be evaluated for susceptibility to $B$. cinerea

a Segregation ratio: homozygous $S L$ : heterozygous: homozygous $S N$

b Plants, homozygous $S N$ were grown to produce $\mathrm{BC}_{3} \mathrm{~S}_{2}$ seeds

observed 4 days post inoculation). Replicate experiments in subsequent weeks showed a low level of infection (mean DI < 20\%) and were therefore discarded. In the first assay, the control $S L$ showed the expected level of susceptibility (Table 2; Finkers et al. 2007a). However, the susceptibility of the controls $S N$ and $S$. habrochaites LYC4 $(\mathrm{SH})$ was higher than previously reported (Finkers et al. 2007a; ten Have et al. 2007) suggesting an overall high disease pressure in this experiment.

Susceptibility to $B$. cinerea in $\mathrm{BC}_{3} \mathrm{~S}_{2}$ lines was assessed in two independent experiments. The mean DI of the two experiments was 29 and $62 \%$, respectively, and yielded, on average, five independent observations for each $\mathrm{BC}_{3} \mathrm{~S}_{2}$ line. The susceptible control $S L$ and the partial resistant control $S H$ showed the expected level of susceptibility (Table 2) but $S N$ was more susceptible than previously reported (ten Have et al. 2007).

Experiments aimed at confirming pQTL3, in the $\mathrm{BC}_{3} \mathrm{~S}_{1}$ population, did not lead to identification of a significant reduction of $L G$, yet the presence of the homozygous $S N$ resistance allele resulted in a reduced LG (Table 5; $P=0.273$ ). A significant reduction was observed while testing the $\mathrm{BC}_{3} \mathrm{~S}_{2}$ lines (Table 6; group baa; $P<0.001$ ). pQTL4, reducing DI, could not significantly be confirmed using either $\mathrm{BC}_{3} \mathrm{~S}_{1}$ (Table 5; $P=0.413$ ) or $\mathrm{BC}_{3} \mathrm{~S}_{2}$ lines (Table 6; group aba; $P=0.645)$. However, in both $\mathrm{BC}_{3} \mathrm{~S}_{1}$ population and $\mathrm{BC}_{3} \mathrm{~S}_{2}$ lines, a reduction in DI was observed in the presence of the $S N$ resistance allele. The LG reducing effect of pQTL9 was not confirmed in the $\mathrm{BC}_{3} \mathrm{~S}_{2}$ lines (Table 6; group aab; $P=1.000$ ). Instead, a $9 \%$ reduction in DI was observed for lines homozygous for the $S N$ allele of pQTL9 $(P=0.665)$.

In addition, $\mathrm{BC}_{3} \mathrm{~S}_{2}$ lines were tested in which a combination of loci were present (Table 6). Two plants were homozygous for the $S N$ alleles of pQTL4 and pQTL9 and showed a lower DI than plants containing either $S N$ alleles of pQTL4 or pQTL9. The $22 \%$ lower DI than $S L$ of these plants was, however, not significant (group abb; $P=0.056$ ). Plants containing a combination of the $S N$ alleles of pQTL3 (higher DI and lower LG compared to $S L$ ) and pQTL9 (lower DI and similar LG compared to $S L$; group bab) were as susceptible as $S L$. However, the observed mean was not deviating from the mean estimated from lines containing each QTL separately. 
Table 5 Effect of pQTL3 or pQTL4 in its respective $\mathrm{BC}_{3} \mathrm{~S}_{1}$ family

\begin{tabular}{|c|c|c|c|c|c|c|c|c|c|}
\hline \multirow[t]{2}{*}{ Marker } & \multirow[t]{2}{*}{ QTL } & \multicolumn{4}{|l|}{ DI (\%) } & \multicolumn{4}{|c|}{ LG (mm/day) } \\
\hline & & $S L^{\mathrm{a}}$ & $h$ & $S N$ & $P^{\mathrm{b}}$ & $S L$ & $h$ & $S N$ & $P$ \\
\hline TG599 & pQTL3-LG & $69(16)$ & $67(17)$ & $72(16)$ & 0.734 & $5.0(16)$ & $5.2(17)$ & $4.3(16)$ & 0.273 \\
\hline TG339 & pQTL4-DI & $68(17)$ & $52(17)$ & $58(15)$ & 0.413 & $6.1(17)$ & $6.2(17)$ & $6.4(15)$ & 0.549 \\
\hline
\end{tabular}

Mean values for disease incidence (DI) and lesion growth (LG) are presented

a $S L$ denotes homozygous for the alleles of S. lycopersicum, $S N$ homozygous for the alleles of S. neorickii, and h describes the heterozygous class. The number of observations within each class is indicated between parentheses

b Significance

Table 6 Estimated mean values for disease incidence $(D I)$ and lesion growth $(L G)$ of the $\mathrm{BC}_{3} \mathrm{~S}_{2}$ lines

\begin{tabular}{llllllrr}
\hline QTL genotype $^{\mathrm{a}}$ & $n^{\mathrm{b}}$ & Mean & DI $(\%)^{\mathrm{c}}$ & SE & Mean & LG (mm/day) & SE \\
\hline aab & 3 & 46 & 0.665 & 7 & 5.8 & 0.28 \\
aba & 8 & 48 & 0.645 & 5 & 4.9 & 0.19 \\
abb & 2 & 33 & 0.056 & 8 & 5.2 & 0.104 & 0.989 \\
baa & 13 & 62 & 1.000 & 4 & 4.5 & $<0.001$ & 0.38 \\
bab & 1 & 61 & 1.000 & 11 & 5.0 & 0.906 & 0.946 \\
$S N$ & 11 & 36 & 0.095 & 7 & 5.1 & 0.35 \\
$S H$ & 4 & 16 & 0.012 & 12 & 1.8 & 0.001 & 0.91 \\
$S L$ & 57 & 55 & & 3 & 5.3 & 0.19 \\
\hline
\end{tabular}

Means of each line/trait were compared to the mean of S. lycopersicum cv. Moneymaker (SL) using a Dunnett test

${ }^{\mathrm{a}}$ aab = QTL genotype at Chromosomes 3, 4, and 9, a = Homozygous $S L$, and b = homozygous $S N$

b $n=$ Number of lines/ $\mathrm{BC}_{3} \mathrm{~S}_{2}$ genotype tested

c Significance

\section{Discussion}

While performing the $B$. cinerea stem assays, susceptibility of the controls varied between experiments (Table 2). In experiments with a harsher infection, quantitative resistance of $S N$ is less robust than the quantitative resistance of $S H$. The higher resistance of SH suggests the presence of a larger number of QTLs, or more effective QTLs. Stem morphology and vascular development of $S H$ stems might also play a role in resistance (Coaker et al. 2002). Variation in the bioassays and environment influences the confirmation of QTLs for resistance to B. cinerea (Finkers et al. 2007a). External influences can be minimized by growing plants in climate rooms but this is logistically not feasible for experiments on this scale.

A correlation between DI and LG was observed in data of the $\mathrm{F}_{3}$ families $(r=0.258 ; P<0.01)$, but no significant correlation was observed in the $\mathrm{SH} \mathrm{\textrm {F } _ { 2 }}$ population ( $r=0.173 ; P>0.05$; Finkers et al. 2007a). These correlations are lower than the correlation observed while testing the $S H$ IL population ( $r=0.65 ; P<0.01$; Finkers et al. 2007b). The heterogeneous genetic background of $\mathrm{F}_{2}$ and $\mathrm{F}_{3}$ plants and/or the type of bioassay used may obscure the obvious relationship which was observed between DI and LG in the SH IL population (Finkers et al. 2007b).

Initially, three pQTLs were identified while analyzing the $\mathrm{F}_{3}$ families. The resistance allele from each pQTL was derived from $S N$. The LG reducing effect of the pQTL3 resistance allele could be confirmed using $\mathrm{BC}_{3} \mathrm{~S}_{2}$ lines. Because of this, pQTL3 will now be referred to as QTL3. No significant confirmation was obtained for the DI reducing effect of the pQTL4 resistance allele. Nevertheless, the presence of the pQTL4 resistance allele reduced DI in all three tested populations. For this reason, this QTL is still regarded as interesting for commercial tomato resistance 
breeding. Criteria for significance were not met due to the lack of replications $\left(\mathrm{BC}_{3} \mathrm{~S}_{1}\right.$ and $\left.\mathrm{BC}_{3} \mathrm{~S}_{2}\right)$ or the lack of the number of lines tested per group $\left(\mathrm{BC}_{3} \mathrm{~S}_{2}\right)$. The LG reducing effect of the pQTL9 resistance allele was not confirmed, but instead we observed a decreased DI. Additional experiments are required to confirm pQTL4 and pQTL9.

The position of each $S N$ QTL was compared to previously mapped QTLs, conferring resistance to $B$. cinerea, from $S H$ (Finkers et al. 2007a, b). Interestingly, both pQTL4 and pQTL9 from $S N$ are located at positions homologous to the SH QTLs Rbcq4a and $R b c q 9$ b (Fig. 1). CAPS analysis of the $S H$ introgression lines (IL) containing Rbcq3 (Finkers et al. 2007b) does not exclude the possibility that SN QTL3 is at a homologous position. We postulate that the three $S N$ (p)QTLs identified in this study have QTLs at homologous positions in $\mathrm{SH}$.

Experiments aimed at confirming the $\mathrm{LG}$ reducing effect of pQTL9 unexpectedly resulted in the identification of a pQTL reducing DI. Previous analysis of the $S H$ IL population, resulted in identification of two QTLs on Chromosome 9: Rbcq9a reducing LG and $R b c q 9 \mathrm{~b}$ reducing DI (Finkers et al. 2007b). The region homologous to Rbcq9a is homozygous $S L$ in this set of $\mathrm{BC}_{3} \mathrm{~S}_{2}$ plants and may explain why only a reduced DI was observed. Future experiments aimed at confirming the reduction in LG should focus on testing lines containing $S N$ alleles in the region homologous to Rbcq9a.

The $S N$ pQTL9 did not confer a reduction in DI in the $S L \times S N \mathrm{~F}_{3}$ population (Table 3), as was also observed for the $S H$ Rbcq9b in the $S L \times S H \mathrm{~F}_{2}$ population (Finkers et al. 2007a). Segregation of multiple DI-reducing loci combined with the underrepresentation of $S N$ alleles for Chromosome 9 might have obscured identification of this locus. Several $\mathrm{BC}_{3} \mathrm{~S}_{2}$ lines contained multiple QTLs. Two plants contained both pQTL4 and pQTL9 (group abb) and the additional reduction in DI of these lines suggests a fully additive model, showing the potential of pyramiding these two pQTLs.

Figure 1 shows a comparison between (p)QTL positions identified in this study and previously mapped QTLs conferring resistance to $B$. cinerea (Finkers et al. 2007b), mapped positions of resistance genes (R-genes), R-gene analogs mapped by Zhang et al. (2002) and QTLs conferring resistance to other diseases (Tables 7, 8). The positions of

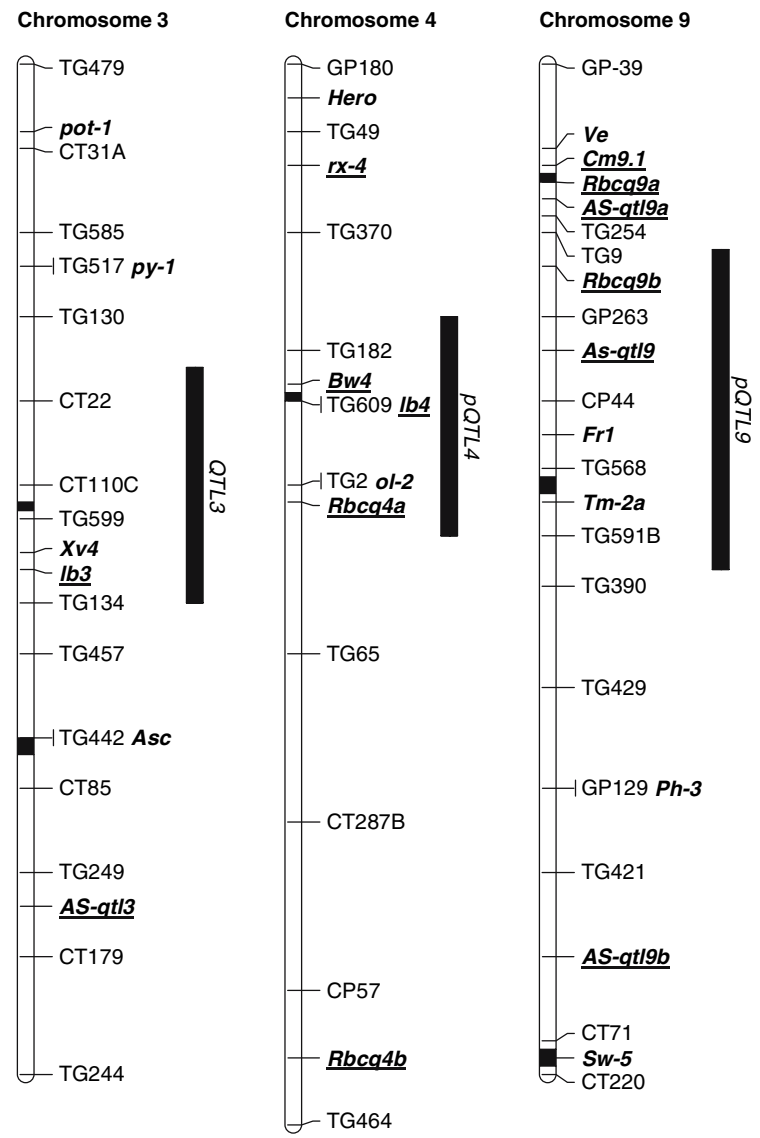

Fig. 1 Overview of resistance loci mapped on tomato Chromosomes 3, 4, and 9: markers are from the core RFLP map (Tanksley et al. 1992). Closed blocks within the bars show the approximate locations of mapped RGAs (Zhang et al. 2002). The approximate locations of monogenic resistance genes $(R$ genes $)$ and quantitative trait loci $(Q T L$, underlined $)$ for disease-resistance are shown. For clarity, some loci were renamed for ease of display. Explanation of abbreviations of the $\mathrm{R}$ genes or QTLs is presented in Tables 7 and 8, respectively. The approximate locations of (p)QTLs identified in this study are presented as bars on the right hand side of each chromosome

B. cinerea QTLs may be homologous with the positions of R-genes or QTLs conferring resistance to Phytophtora infestans and Xanthomonas campestris (Chromosome 3); Ralstonia solanacearum, $P$. infestans, and O. neolycopersici (Chromosome 4); Alternaria solani, Fusarium oxysporum, and TMV (Chromosome 9). It remains to be determined whether loci at homologues positions involve the same genes triggering a general defense mechanism such as papillae formation or phytoalexin production 
Table 7 Qualitative resistance genes mapped on the tomato Chromosomes 3, 4, and 9

\begin{tabular}{|c|c|c|c|c|c|}
\hline Chromosome & Locus & Pathogen & Common name & $\begin{array}{l}\text { Resistance } \\
\text { originating from }^{\mathrm{a}}\end{array}$ & Reference \\
\hline 3 & $A s c$ & Alternaria alternata & Black mold & $\begin{array}{l}\text { S. chilense G1.1701, S. } \\
\text { chmielewskii } \\
\text { CPRO731089, S. neorickii } \\
\text { G1.1604, S. pennellii LA716 } \\
\text { and G1.1611, L. peruvianum } \\
\text { G1.1860 and } S . \\
\text { pimpinellifolium } \\
\text { G1.1704 }\end{array}$ & $\begin{array}{l}\text { van der Biezen et al. } \\
\quad(1995)\end{array}$ \\
\hline 9 & $F r 1$ & Fusarium oxysporum & $\begin{array}{l}\text { Fusarium vascular } \\
\text { wilt }\end{array}$ & L. peruvianum & Vakalounakis et al. (1997) \\
\hline 4 & Hero & $\begin{array}{l}\text { Globodera } \\
\quad \text { rostochiensis }\end{array}$ & & S. pimpinellifolium LA1792 & Ganal et al. (1995) \\
\hline 4 & $o l-2$ & Oidium neolycopersici & Powdery mildew & $\begin{array}{l}\text { S. lycopersicum var. } \\
\text { cerasiforme }\end{array}$ & $\begin{array}{l}\text { Ciccarese et al. (1998) } \\
\text { and De Giovanni et al. } \\
(2004)\end{array}$ \\
\hline 9 & $P h-3$ & $\begin{array}{l}\text { Phytophthora } \\
\text { infestans }\end{array}$ & Late blight & S. pimpinellifolium L3708 & Chunwongse et al. (2002) \\
\hline 3 & pot-1 & Potato virus $\mathrm{Y}$ & PVY & S. habrochaites PI247087 & $\begin{array}{l}\text { Legnani et al. (1995) and } \\
\text { Parrella et al. (2002) }\end{array}$ \\
\hline 3 & $P y-1$ & $\begin{array}{c}\text { Pyrenochaeta } \\
\text { lycopersici }\end{array}$ & Corky root rot & L. peruvianum & Doganlar et al. (1998) \\
\hline 3 & pot-1 & Tobacco etch virus & TEV & S. habrochaites PI 247087 & Parrella et al. (2002) \\
\hline 9 & $\begin{array}{r}T m- \\
2 a\end{array}$ & Tomato mosaic virus & TMV & L. peruvianum & Young et al. (1988) \\
\hline 9 & $S w-5$ & $\begin{array}{l}\text { Tomato spotted wilt } \\
\text { virus }\end{array}$ & TSWV & L. peruvianum & Stevens et al. $(1991,1995)$ \\
\hline 9 & $V e$ & Verticillium dahliae & Verticillium wilt & L. peruvianum & $\begin{array}{l}\text { Zamir et al. (1993) and } \\
\text { Diwan et al. (1999) }\end{array}$ \\
\hline 3 & $X v 4$ & $\begin{array}{c}\text { Xanthomonas } \\
\text { campestris }\end{array}$ & Bacterial spot & S. pennellii LA716 & Astua-Monge et al. (2000) \\
\hline
\end{tabular}

\footnotetext{
a According to the new nomenclature L. peruvianum is divided 4 Solanum species (Peralta et al. 2005). This division is unknown for most accessions mentioned in this table
}

or whether the observed homologous positions are coincidental. The recessive gene ol-2, identified in S. lycopersicum var. cerasiforme and mapped at a position homologous to pQTL4, is involved in papillae formation (Bai et al. 2005). The observation that pQTL4 acts dominant implies that resistance to $B$. cinerea and to $O$. neolycopersici cannot be conferred by the same gene. However, it cannot be excluded that each species contains a similar ancestral gene, which has diverged into alleles conferring specificity to different pathogens. The isolation of $B$. cinerea R-genes, followed by complementation and subsequent testing of these plants for resistance to multiple pathogens, might resolve such questions.
The resistance alleles of pQTL4 and Rbcq4a act dominantly in reducing DI (Finkers et al. 2007a). Over-dominance of pQTL4 was observed in the $\mathrm{BC}_{3} \mathrm{~S}_{1}$ population, but an independent confirmation is needed. Dominant QTLs for resistance to $B$. cinerea are advantageous in commercial $F_{1}$ hybrid cultivar development. Disease tests, using the stem assay, resulted in identification of QTLs either reducing DI or reducing LG (Finkers et al. 2007a). QTLs generally contributed to both a lower DI and LG in a greenhouse assay on mature plants (Finkers et al. 2007b). QTL3 and pQTL4 might therefore be effective in reducing both DI and LG when used in commercial breeding programs. Besides $S$. habrochaites LYC4, S. neorickii 
Table 8 Quantitative resistance loci with at least one locus mapped on the tomato Chromosomes 3, 4 or 9

\begin{tabular}{|c|c|c|c|c|c|}
\hline Chromosome & Locus & Pathogen & $\begin{array}{l}\text { Common } \\
\text { name }\end{array}$ & $\begin{array}{l}\text { Resistance originating } \\
\text { from }\end{array}$ & Reference \\
\hline 9 & As-QTL9 & Alternaria solani & Early blight & S. arcanum LA2157 & Chaerani et al. (2006) \\
\hline 3 and 9 & $\begin{array}{l}A S-Q T L 3 \text { and } \\
A S-Q T L 9 a \& b\end{array}$ & Alternaria solani & Early blight & $\begin{array}{l}\text { S. habrochaites } \\
\text { PI126445 }\end{array}$ & $\begin{array}{l}\text { Foolad et al. (2002) and } \\
\text { Zhang et al. (2003) }\end{array}$ \\
\hline 3,4 , and 9 & $\begin{array}{l}R b c q 3, R b c q 4 a \& b \\
\text { and } R b c q 9 a \& b\end{array}$ & Botrytis cinerea & Gray mold & S. habrochaites LYC4 & Finkers et al. $(2007 \mathrm{a}, \mathrm{b})$ \\
\hline 3,4 , and 9 & $\begin{array}{l}Q T L 3, p Q T L 4, \text { and } \\
\quad p Q T L 9\end{array}$ & Botrytis cinerea & Gray mold & S. neorickii G1.1601 & This study \\
\hline 9 & Cm9.1 & $\begin{array}{l}\text { Clavibacter } \\
\quad \text { michiganensis }\end{array}$ & $\begin{array}{r}\text { Bacterial } \\
\text { canker }\end{array}$ & S. arcanum LA2157 & van Heusden et al. (1999) \\
\hline 3 and 4 & $l b 3$ and $l b 4$ & $\begin{array}{c}\text { Phytophtora } \\
\text { infestans }\end{array}$ & Late blight & S. habrochaites LA2099 & $\begin{array}{l}\text { Brouwer et al. (2004) and } \\
\text { Brouwer and St. Clair } \\
(2004)\end{array}$ \\
\hline 4 & $B w 4$ & $\begin{array}{l}\text { Ralstonia } \\
\quad \text { solanacearum }\end{array}$ & Bacterial wilt & $\begin{array}{l}\text { S. lycopersicum Hawaii } \\
7996\end{array}$ & Thoquet et al. (1996a, b) \\
\hline 4 & $r x-4$ & $\begin{array}{c}\text { Xanthomonas } \\
\text { campestris }\end{array}$ & Bacterial spot & $\begin{array}{l}\text { S. lycopersicum Hawai } \\
7998\end{array}$ & Yang et al. (2005) \\
\hline
\end{tabular}

G1.1601 is an alternative source for QTLs conferring resistance to $B$. cinerea.

Acknowledgments This project was sponsored by the Dutch Technology Foundation (STW, project WBI.4172) and De Ruiter Seeds R\&D BV, The Netherlands. The authors would like to thank an anonymous referee for his useful comments, Pham Thi Thu Huong and Yaxin Zhang for their contributions and the staff at Unifarm for taking care of the plants.

\section{References}

Astua-Monge G, Minsavage GV, Stall RE, Vallejos CE, Davis MJ, Jones JB (2000) Xv4-vrxv4: a new gene-for-gene interaction identified between Xanthomonas campestris pv. vesicatoria race T3 and the wild tomato relative Lycopersicon pennellii. Mol Plant Microbe Interact 13:1346-1355

Bai Y, Feng XH, van der Hulst R, Lindhout P (2004) A set of simple PCR markers converted from sequence specific RFLP markers on tomato Chromosomes 9 to 12 . Mol Breed 13:281-287

Bai Y, Huang CC, van der Hulst R, Meijer Dekens F, Bonnema G, Lindhout P (2003) QTLs for tomato powdery mildew resistance (Oidium lycopersici) in Lycopersicon parviflorum G1.1601 co-localize with two qualitative powdery mildew resistance genes. Mol Plant Microbe Interact 16:169-176

Bai Y, van der Hulst R, Bonnema G, Marcel TC, Meijer-Dekens F, Niks RE, Lindhout P (2005) Tomato defense to Oidium neolycopersici: dominant $\mathrm{Ol}$ genes confer isolatedependent resistance via a different mechanism than recessive ol-2. Mol Plant Microbe Interact 18:354-362

Benito EP, ten Have A, van't Klooster JW, van Kan JAL (1998) Fungal and plant gene expression during synchronized infection of tomato leaves by Botrytis cinerea. Eur J Plant Pathol 104:207-220

Brouwer DJ, Jones ES, St. Clair DA (2004) QTL analysis of quantitative resistance to Phytophthora infestans (late blight) in tomato and comparisons with potato. Genome 47:475-492

Brouwer DJ, St. Clair DA (2004) Fine mapping of three quantitative trait loci for late blight resistance in tomato using near isogenic lines (NILs) and sub-NILs. Theor Appl Genet 108:628-638

Chaerani R, Smulders MJM, van der Linden CG, Vosman B, Stam P, Voorrips RE (2006) QTL identification for early blight resistance (Alternaria solani) in a Solanum lycopersicum $\times$ S. arcanum cross. Theor Appl Genet 114:439-450

Chunwongse J, Chunwongse C, Black L, Hanson P (2002) Molecular mapping of the $P h-3$ gene for late blight resistance in tomato. J Hortic Sci Biotechnol 77:281-286

Ciccarese F, Amenduni M, Schiavone D, Cirulli M (1998) Occurrence and inheritance of resistance to powdery mildew (Oidium lycopersici) in Lycopersicon species. Plant Pathol 47:417-419

Coaker GL, Meulia T, Kabelka EA, Jones AJ, Francis DM (2002) A QTL controlling stem morphology and vascular development in Lycopersicon esculentum $\times$ Lycopersicon hirsutum (Solanaceae) crosses is located on chromosome 2. Am J Bot 89:1859-1866

De Giovanni C, Dell'Orco P, Bruno A, Ciccarese F, Lotti C, Ricciardi L (2004) Identification of PCR-based markers (RAPD, AFLP) linked to a novel powdery mildew resistance gene (ol-2) in tomato. Plant Sci 166:41-48

Diwan N, Fluhr R, Eshed Y, Zamir D, Tanksley SD (1999) Mapping of $V e$ in tomato: a gene conferring resistance to the broad-spectrum pathogen, Verticillium dahliae race 1. Theor Appl Genet 98:315-319

Doganlar S, Dodson J, Gabor B, BeckBunn T, Crossman C, Tanksley SD (1998) Molecular mapping of the $p y-1$ gene 
for resistance to corky root rot (Pyrenochaeta lycopersici) in tomato. Theor Appl Genet 97:784-788

Dunnett CW (1955) A multiple comparison procedure for comparing several treatments with a control. J Am Stat Assoc 50:1096-1121

Egashira H, Kuwashima A, Ishiguro H, Fukushima K, Kaya T, Imanishi S (2000) Screening of wild accessions resistant to gray mold (Botrytis cinerea Pers.) in Lycopersicon. Acta Physiol Plant 22:324-326

Elad Y, Williamson B, Tudzynski P, Delen N (2004) Botrytis: biology, pathology and control, 1st edn. Kluwer, Dordrecht

Finkers R, van den Berg P, van Berloo R, ten Have A, van Heusden AW, van Kan JAL, Lindhout P (2007a) Three QTLs for Botrytis cinerea resistance in tomato. Theor Appl Genet 114:585-593

Finkers R, van Heusden AW, Meijer-Dekens F, van Kan JAL, Maris P, Lindhout P (2007b) The construction of a Solanum habrochaites LYC4 introgression line population and the identification of QTLs for resistance to Botrytis cinerea. Theor Appl Genet 114:1071-1080

Foolad MR, Zhang LP, Khan AA, Nino Liu D, Liln GY (2002) Identification of QTLs for early blight (Alternaria solani) resistance in tomato using backcross populations of a Lycopersicon esculentum $\times$ L. hirsutum cross. Theor Appl Genet 104:945-958

Ganal MW, Simon R, Brommonschenkel S, Arndt M, Phillips MS, Tanksley SD, Kumar A (1995) Genetic mapping of a wide spectrum nematode resistance gene (Hero) against Globodera rostochiensis in tomato. Mol Plant Microbe Interact 8:886-891

Jarvis WR (1977) Botryotinia and Botrytis species: taxonomy, physiology, and pathogenicity; a guide to the literature. Monograph 15

Legnani R, Selassie KG, Womdim RN, Gognalons P, Moretti A, Laterrot H, Marchoux G (1995) Evaluation and inheritance of the Lycopersicon hirsutum resistance against potato virus Y. Euphytica 86:219-226

Nicot PC, Moretti A, Romiti C, Bardin M, Caranta C, Ferrière H (2002) Differences in susceptibility of pruning wounds and leaves to infection by Botrytis cinerea among wild tomato accessions. TGC Rep 52:24-26

Parrella G, Ruffel S, Moretti A, Morel C, Palloix A, Caranta C (2002) Recessive resistance genes against potyviruses are localized in colinear genomic regions of the tomato (Lycopersicon spp.) and pepper (Capsicum spp.) genomes. Theor Appl Genet 105:855-861

Peralta IE, Knapp SK, Spooner DM (2005) New species of wild tomatoes (Solanum section Lycopersicon: Solanaceae) from Northern Peru. Syst Bot 30:424-434

Sobir, Ohmori T, Murata M, Motoyoshi F (2000) Molecular characterization of the SCAR markers tightly linked to the Tm-2 locus of the genus Lycopersicon. Theor Appl Genet 101:64-69

Stevens MR, Lamb EM, Rhoads DD (1995) Mapping the $S w-5$ locus for tomato spotted wilt virus resistance in tomatoes using RAPD and RFLP analyses. Theor Appl Genet 90:451-456

Stevens MR, Scott SJ, Gergerich RC (1991) Inheritance of a gene for resistance to tomato spotted wilt virus (TSWV) from Lycopersicon peruvianum Mill. Euphytica 59:9-17
Tanksley SD, Ganal MW, Prince JP, de Vicente MC, Bonierbale MW, Broun P, Fulton TM, Giovannoni JJ, Grandillo S, Martin GB (1992) High density molecular linkage maps of the tomato and potato genomes. Genetics 132:1141-1160

ten Have A, van Berloo R, Lindhout P, van Kan JAL (2007) Partial stem and leaf resistance against the fungal pathogen Botrytis cinerea in wild relatives of tomato. Eur J Plant Pathol 117:153-166

Thoquet P, Olivier J, Sperisen C, Rogowsky P, Laterrot H, Grimsley N (1996a) Quantitative trait loci determining resistance to bacterial wilt in tomato cultivar Hawaii7996. Mol Plant Microbe Interact 9:826-836

Thoquet P, Olivier J, Sperisen C, Rogowsky P, Prior P, Anais G, Mangin B, Bazin B, Nazer R, Grimsley N (1996b) Polygenic resistance of tomato plants to bacterial wilt in the French West Indies. Mol Plant Microbe Interact 9:837-842

Urbasch I (1986) Resistenz verschiedener Kultur- und Wildtomatenpflanzen (Lycopersicon spp.) gegenüber Botrytis cinerea Pers. J Phytopathol 116:344-351

Vakalounakis DJ, Laterrot H, Moretti A, Ligoxigakis EK, Smardas K (1997) Linkage between Frl (Fusarium oxysporum $\mathrm{f}$ sp radicis-lycopersici resistance) and Tm-2 (tobacco mosaic virus resistance-2) loci in tomato (Lycopersicon esculentum). Ann Appl Biol 130:319-323

van der Biezen EA, Glagotskaya T, Overduin B, Nijkamp HJJ, Hille J (1995) Inheritance and genetic mapping of resistance to Alternaria alternata f.sp. lycopersici in Lycopersicon pennellii. Mol Gen Genet 247:453-461

van Heusden AW, Koornneef M, Voorrips RE, Bruggemann W, Pet G, Vrielink van Ginkel R, Chen X, Lindhout P (1999) Three QTLs from Lycopersicon peruvianum confer a high level of resistance to Clavibacter michiganensis ssp michiganensis. Theor Appl Genet 99:1068-1074

van Ooijen JW (2003) MapQTL ${ }^{\mathbb{R}}$ 5.0, Software for the calculation of QTL positions on genetic maps. Kyazma B.V., Wageningen, The Netherlands

van Ooijen JW, Voorrips RE (2001) Joinmap ${ }^{\mathbb{B}}$ 3.0, Software for the calculation of genetic linkage maps

Voorrips RE (2002) MapChart: software for the graphical presentation of linkage maps and QTLs. J Hered 93:77-78

Yang WC, Sacks EJ, Ivey MLL, Miller SA, Francis DM (2005) Resistance in Lycopersicon esculentum intraspeciflc crosses to race T1 strains of Xanthomonas campestris pv. vesicatoria causing bacterial spot of tomato. Phytopathology 95:519-527

Young ND, Zamir D, Ganal MW, Tanksley SD (1988) Use of isogenic lines and simultaneous probing to identify DNA markers tightly linked to the $T m-2 a$ gene in tomato. Genetics 120:579-585

Zamir D, Bolkan H, Juvik JA, Watterson JC, Tanksley D (1993) New evidence for placement of $V e$ - the gene for resistance to Verticillium race 1. TGC report 43

Zhang LP, Khan A, Nino Liu D, Foolad MR (2002) A molecular linkage map of tomato displaying chromosomal locations of resistance gene analogs based on a Lycopersicon esculentum $\times$ L. hirsutum cross. Genome 45:133-146

Zhang LP, Lin GY, Nino Liu D, Foolad MR (2003) Mapping QTLs conferring early blight (Alternaria solani) resistance in a Lycopersicon esculentum $\times$ L. hirsutum cross by selective genotyping. Mol Breed 12:3-19 